\begin{tabular}{|c|c|c|}
\hline & $\begin{array}{l}\text { International Journal of Environment, Agriculture and Biotechnology } \\
\qquad \text { Vol-6, Issue-1; Jan-Feb, } 2021\end{array}$ & $(\mathrm { T } \longdiv { \mathrm { m } }$ \\
\hline IJEAB & $\begin{array}{c}\text { Journal Home Page Available: } \underline{\text { https://ijeab.com/ }} \\
\text { Journal DOI: } \underline{10.22161 / \text { ijeab }}\end{array}$ & \\
\hline
\end{tabular}

\title{
Study of Some Parameters Influencing the post mortem PH of Carcass's muscles of Dromedaries Slaughtered at the Touggourt Slaughterhouse. Algeria
}

\author{
BENAISSA Atika ${ }^{1}$, BABELHADJ Baaissa ${ }^{1,2}$ TOUHAMI Imene ${ }^{1}$ and DJALFAOUI \\ Zineb $^{3}$
}

\author{
${ }^{1}$ Laboratory of Ecosystems Protection in Arid and Semi-Arid Zones, University of Kasdi Merbah, 30000 Ouargla, Algeria \\ ${ }^{2}$ Ecole Normale Supérieure de Ouargla, Algeria \\ ${ }^{3}$ Laboratory of Palm Date Cultuvations Research "Phœnix”, Kasdi Merbah University of Ouargla, 30000 Ouargla, Algeria.
}

Received: 02 Nov 2020; Received in revised form: 05 Jan 2021; Accepted: 25 Jan 2021; Available online: 16 Feb 2021

(C)2021 The Author(s). Published by Infogain Publication. This is an open access article under the CC BY license

(https://creativecommons.org/licenses/by/4.0/).

\begin{abstract}
This work aims to study Biological and abiological factors influencing the postmortems hydrogen potential $(\mathrm{pH})$ of four muscles, of twenty dromedary's carcasses slaughtered at the slaughterhouse in Touggourt municipality, Algeria. The temperature and $\mathrm{pH}$ were measured at one hour and a half after slaughtering, skinning and evisceration of carcasses. Electronic thermometer and electronic pH meter were used with under-implementation of breeder's know-how and knowledge of veterinarian. The 4 muscles are respectively: Cleido- mastoidien, Semi membranosus, Triceps Brachii and Psoas major. The dromedaries studied are from two populations : The Sahraoui and the Targui. The sample is composed of males and females between 1 and 7 years of age, coming from three types of livestock farming (Intensive, Semi-intensive and Extensive), and before slaughtering the animals were in different housing periods. The statistical analysis is carried out by the SPSS (statistical software) in two "2" steps: the pH overage varies according to the muscle's type, with a highest values recorded in the Triceps Brachii (6.99 $\leq p H \leq 7.14)$, then the Cleido-mastoidian with a pH of 6.98 to 6.84 and for the Semi membranosus and Psoas major which are the closest, with a pH respectively of 6.82 to 6.62 and 6.80 to 6.65. Regarding parameters linked to the animal, the age affects the $\mathrm{pH}$ with a strong negative correlation ( $r=-0.99 ; p>0.0001)$. The carcass weight has a negative relationship $(r=-0.98 ; p>0.0003)$. Then sex, while the race is not related to $\mathrm{pH}$. For the parameters controlled by humans, the fasting time is at the origin of the increase in post-mortem $\mathrm{pH}$ values, corresponding to a positive correlation ( $r$ 0.74; $p>0.0007)$. Also, the mode of livestock farming affects this parameter.
\end{abstract}

Keywords-dromedary, muscle, post mortem $\mathrm{pH}$, slaughterhouse, Touggourt.

\section{INTRODUCTION}

The dromedary (Camelus dromedarius) is a species of domestic mammal from the family of camelids and the genus Camelus (Charnot, 1959). It is an animal which its morphology, physiology and particular behavior allow it to adapt better than any other breeding animal to the desert conditions.

In Algeria, the dromedary plays a primordial social and economical role, it has been associated with life forms in arid and semi-arid pastoral areas. It meets the multiple needs of the population by providing milk, meat and serving as a means transportation and for agricultural work as well (Siboukeur, 2007).

According to M.A.D.R, in 2013, the headcount in Algeria is estimated at 344,015 head. The dromedary, thanks to its high carcass yield, its meat is appreciated and consumed on a large scale in Algerian Sahara (Faye et al, 2013).

Picard et al, (2002), report that meat quality varies according to not only biological factors for both antemortem and post-mortem. According to Boudjellal et al, (2008), acidification of the muscle is considered as major determinant of meat quality. Benaissa et al, (2014) 
obtaine that the evolution of post-mortem $\mathrm{pH}$ is characterized by a rapid drop during the first eight hours after slaughter, followed by a slowdown.

As defined by Hocquette et al, (2012), the post-mortem $\mathrm{pH}$ is influenced by biological factors linked to the animal (species, race, age, sex and type of muscle) and factors controlled by humans that could be from animal's stress before and after slaughter, feeding and livestock farming mode.

The purpose of this study is the influence assessment of some parameters, whether related or not to the animal, on post-mortem $\mathrm{pH}$ of four types of carcass's muscle from dromedaries that have been slaughtered at the slaughterhouse of Touggourt municipality.

\section{MATERIAL AND METHODS}

\section{1. Presentation of Touggourt municipal slaughterhouse}

The Touggourt slaughterhouse is one of the red meat supplier (beef, sheep, goat and camel) in southern Algeria. It covers an area of 23363 square meters. It contines an animals rest area and two slaughter and evisceration rooms with two offices one for the veterinarian and the other for butchers reception and a changing room (Agricultural Services Directorate 2018).

\subsection{Experimental methodology}

To study parameters influencing the post mortem $\mathrm{pH}$ of dromedaries muscles, we used 4 types of muscles from young animals ( 1 to 4 years old) and young adults (5 to 7 years old) from two populations, The Sahrawi and The Targui, the most slaughtered in the study region. These animals are slaughtered according to the Muslim rite "ENAHR" to be marketed. The four muscles studied are:

$$
\begin{array}{lllll}
\checkmark & \text { Neck muscle : Cleido Mastoidien } & \text { (CM) } \\
\checkmark & \text { Thigh muscle : Semi membranosus } & \text { (SM) } \\
\checkmark & \text { Shoulder muscle : Triceps Brachii } & \text { (TB) } \\
\checkmark & \text { Back muscle : Psoas major }(\mathrm{PM})
\end{array}
$$

Cleido Mastoidien \& Semi membranosus are two muscles often used as indicator muscles for assessing the tenderness of red meat for beef and sheep (KLONT et $a l$, 1998 et VERGARA et al, 1999). Triceps Brachii \& Psoas major are indicators of red meat organoleptic quality assessment (Kamoun, 1995).

\section{Identification of parameters related to the animals}

The determination of the animal's race or more precisely its population, aims to characterize and compare the morphology of 20 dromedaries from two populations (the Sahrawi 14 animals and the Targui 6 animals). For this, we called in veterinarians. This choice is not fortuitous because the Sahrawi population corresponds to the Northerns Sahara race and Targuis correspond to Tamanrasset's Population (Ouled Laid, 2008). Direct observation of animal's reproductive system was used to determine the studied animals sex. While the age of these dromedaries has been assessed by veterinarians based on the animal's dentition. Knowing that, the presence of incisors on the upper jaw and canines on both jaws is the species feature. For the carcass weight, in absence of an appropriate weighting tool, the weight was determined after the carcass cutting by summing different separated parts which comprises nine pieces: The neck, the two shoulders, the thoracic part, the right ribs, the left ribs, the lumbar part and the two thighs. These weighings were carried out using an electronic "Crane Scale Cap" with a maximum capacity of $150 \mathrm{~kg}$.

\section{Identification of parameters controlled by humans}

To determine the breeding system for these camels we used the information given by camel drivers. So 3 types of camel farming system were deduced: extensive, intensive and semi-intensive. To determine the duration of fasting for the dromedaries studied, we appealed to the breeders or owners of these animals.

\section{Location of muscles studied and measurement of their} temperature and $\mathrm{pH}$

The 4 muscles studied are located after skinning, evisceration and cutting of the carcasses. The intramuscular temperature of the 4 muscles is expressed in degrees Celsius. It is directly read using an electronic thermometer "Digital Thermometer", equipped with a penetrating probe allowing the measurement of the temperature at the heart of the muscle. Three measurements are made for each muscle and the temperature recorded is an average of three readings taken. Post mortem $\mathrm{pH}$ is the focus of our study. The measurement of this parameter is carried out by a direct method, using an electronic $\mathrm{pH}$ meter ' $\mathrm{pH}$ Meter 8000', equipped with a penetrating probe allowing a $\mathrm{pH}$ measurement at the muscle heart. The reported $\mathrm{pH}$ value is an average of three readings for each muscle.

\section{Data analysis and processing}

Analysis and processing of the measured data is carried out by the SPSS (statistical software) in two 2 steps:

First step, served to rearrange the measured $\mathrm{pH}$ values in tables to facilitate the calculation of the average for each muscle. these measurments are taken from 20 animals according to the parameters studied (breed, sex, age, breeding method, warm carcass's weight, fasting time and temperature).

Second step, at this stage we applied different graphical forms like figures to present the results in a clearer way which helps to show variations in $\mathrm{pH}$ according to the studied parameters. 


\section{RESULTS}

\subsection{Influence of parameters related to animal on post- mortem $\mathrm{pH}$}

Influence of the animal breed

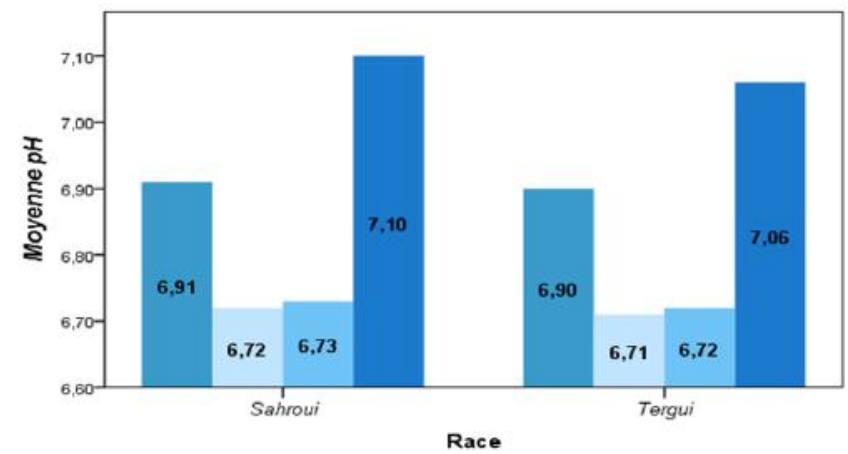

Fig 1 : post-mortem $\mathrm{pH}$ of the four muscles of both races : Sahraoui and Targui

To assess the average $\mathrm{pH}$ value recorded for each muscle, we calculate the average $\mathrm{pH}$ measured on all the muscles studied of the same type, from different carcasses and from the same population. The average $\mathrm{pH}$ values recorded for the 4 muscles studied, from animals belonging to both populations, were all close to neutrality. The maximum averages were recorded on the TB muscle for both breeds with 7.10 and 7.06 respectively for the Sahrawi and the Targui. While the minimum values were taken for the SM muscle for the two animal races (6.72 for the Sahrawi and 6.71 for the Targui). A slight decrease in this parameter for the 4 muscles was noted in the Targui population. The $\mathrm{pH}$ follows the same profile for both populations, this parameter was influenced by the muscle type more than the breed (Figure 1).

\section{Influence of the animal's sex}

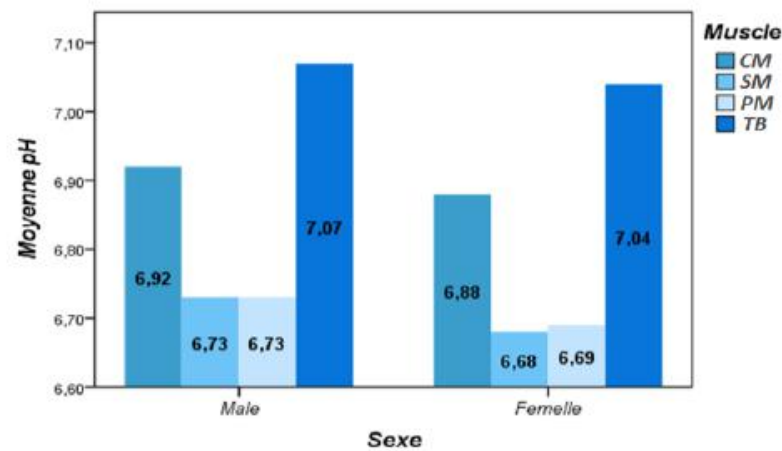

Fig 2: The four muscles post-mortem $\mathrm{pH}$ according to sex;Males and Females

To assess the average $\mathrm{pH}$ value recorded for each muscle, we calculated the average of the $\mathrm{pH}$ measured on all the muscles studied. These muscles are from the same type of different analyzed carcasses and from the same sex without taking into account the animal's race. The postmortem $\mathrm{pH}$ of all muscles studied were close to neutral; values of this parameter vary between 7.07 for male's TB and 6.68 for female's SM. A difference between the $\mathrm{pH}$ values recorded for the same muscle but coming from different sexes ; the highest values are measured on muscles obtained from male animals (Figure 2).

Influence of animal's age

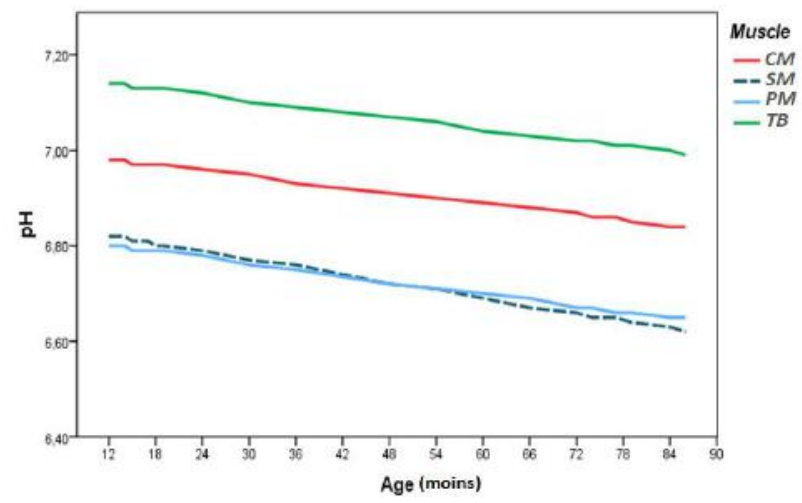

Fig 3 : Influence of animal's age on the post-mortem $\mathrm{pH}$ of the four muscles.

The average $\mathrm{pH}$ value calculation recorded for each muscle, is obtained by calculating the $\mathrm{pH}$ average measured on all muscles of the same type, studied from different carcasses from animals of the same age category without taking into account the animal race.

The $\mathrm{pH}$ follows the same profile for the 4 types of muscles studied. A decline in this parameter and with the same amplitude is recorded with the animal's age increase (Figure 3). This indicates that there is a mechanism affecting the muscles or more precisely affecting the muscle fibers in the same way.

Influence of carcasses weight

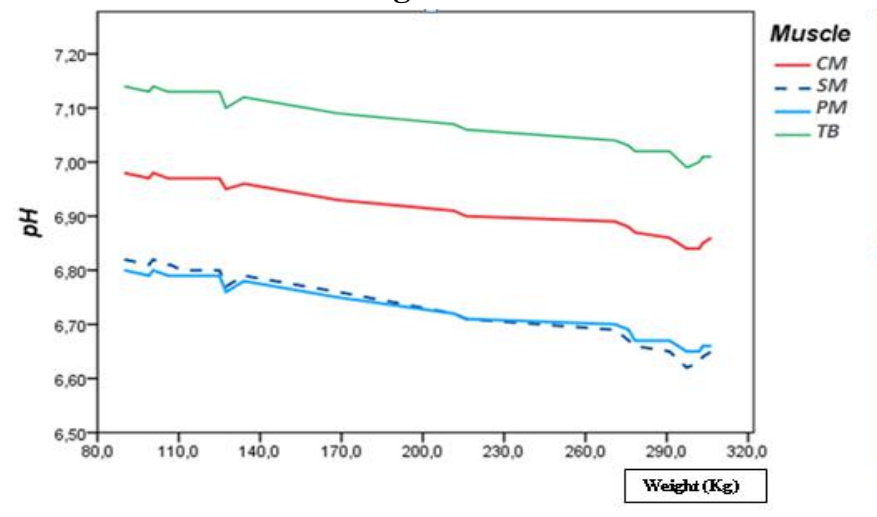

Fig 4: Influence of carcass weight on the four muscles post-mortem $\mathrm{pH}$.

The average $\mathrm{pH}$ calculation recorded for each muscle, is obtained by calculating the average of the $\mathrm{pH}$ measured on all same type of studied muscles from different carcasses, taking into account their weight and neglecting the animal race and the age category. All curves present the same shape for all muscles. A fall in this parameter is noted with 
the increase in carcass weight for the four muscles types (Figure 4).

\subsection{Variations of post-mortem $\mathrm{pH}$ according to parameters controlled by humans \\ Influence of livestock farming mode}

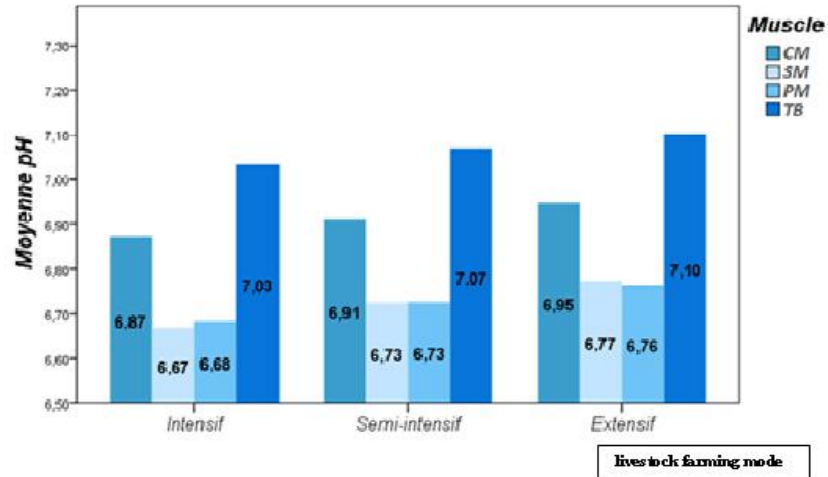

Fig 5 : Influence of livestock farming mode on postmortem $\mathrm{pH}$ of the four muscles.

The average $\mathrm{pH}$ evaluation recorded for each muscle, is obtained by calculating an average of the $\mathrm{pH}$ measured on all muscles that have same type. And whome are coming from animals of a same breeding type, without considering neither the breed, the age nor the sex of the animal. Variations in post-mortem $\mathrm{pH}$ between the 4 types of muscle and for the same muscle as well, are recorded depending on the farming method. Values of this parameter vary between 7.10 to 6.67 recorded respectively on the muscles;TB (extensive) and SM (intensive). The lowest values are noted in dromedaries from intensive breeding, while the highest ones are recorded from extensive livestock farming (Figure 5).

\section{Influence of fasting time}

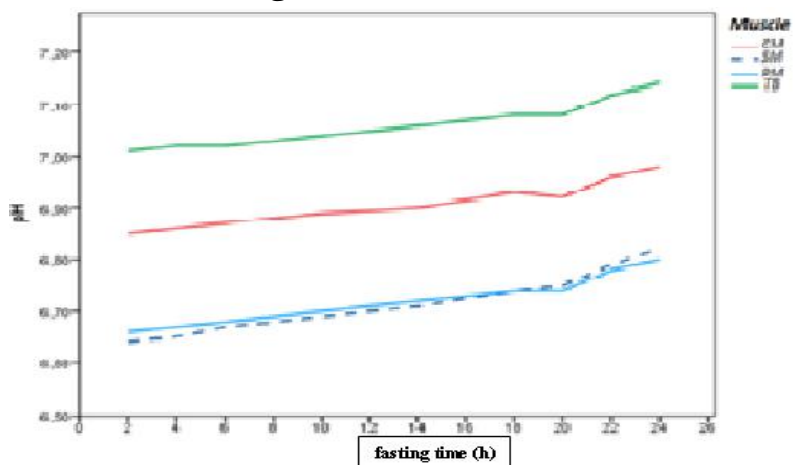

Fig 6: Influence of the fasting time on the post-mortem $\mathrm{pH}$ of the four muscles.
Considering the animal's fasting time and neglecting its race and regardless of its age, carcasses are used in order to obtaine the average $\mathrm{pH}$ recorded for each muscle. The average $\mathrm{pH}$ measured is calculated of all muscles having the same type of carcasses. A variation in $\mathrm{pH}$ is noted between the muscles according to dromedaries fasting duration. $\mathrm{pH}$ values increased linearly with fasting time up to 20 hours, after this duration they are significantly higher. Therefore, more animal's fasting time before the butchery is longer more the possibility of acquiring a meat with $\mathrm{pH}$ close to 7 is bigger (Face 6).

Influence of carcass's temperature

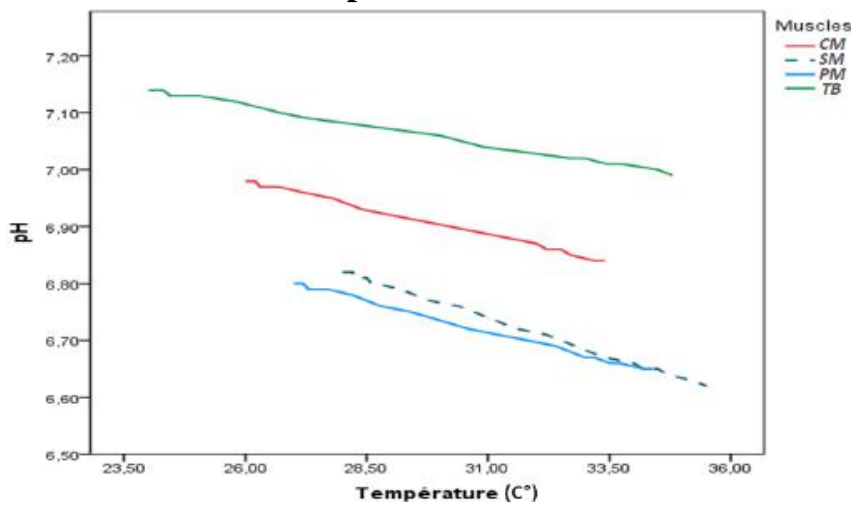

Fig 7 : Relationship between temperature and postmortem $\mathrm{pH}$ of the four muscles.

The average value of $\mathrm{pH}$ recorded for each muscle, is obtained by calculating the measured $\mathrm{pH}$ average on all the muscles of the same type of different carcasses, taking into account the muscle temperature and neglecting the animal's race and age category. For all muscles, a higher post-mortem temperature is accompanied by a lower $\mathrm{pH}$ value p. m. Knowing that sampled temperatures vary between a maximum of $36^{\circ} \mathrm{C}$ and a minimum of $24^{\circ} \mathrm{C}$. This variability could be explained by muscle's exposure to the air after carcasses cutting and its richness in fat (Figure 7).

\subsection{Correlation analysis}

Table $1:$ The correlation matrix between the studied parameters

\begin{tabular}{|l|l|l|l|l|l|l|l|}
\hline & Race & Sex & Age & PC & ME & TMJ & TC \\
\hline Race & $\mathbf{1}$ & & & & & \\
\hline Sex & $\mathbf{- 0 , 1 9 0}$ & $\mathbf{1}$ & & & & \\
\hline Age & $\mathbf{0 , 0 0 3}$ & $\mathbf{0 , 7 0 1}$ & $\mathbf{1}$ & & & \\
\hline
\end{tabular}




\begin{tabular}{|l|l|l|l|l|l|l|l|}
\hline CW & $\mathbf{0 , 0 1 6}$ & $\mathbf{0 , 6 5 9}$ & $\mathbf{0 , 9 8 9}$ & $\mathbf{1}$ & & & \\
\hline LFM & $\mathbf{- 0 , 1 5 0}$ & $-\mathbf{0 , 4 8 4}$ & $\mathbf{- 0 , 4 5 6}$ & $\mathbf{- 0 , 5 3 2}$ & $\mathbf{1}$ & & \\
\hline FT & $-\mathbf{0 , 1 8 7}$ & $-\mathbf{0 , 4 2 4}$ & $-\mathbf{0 , 7 5 1}$ & $-\mathbf{0 , 7 9 8}$ & $\mathbf{0 , 5 8 9}$ & $\mathbf{1}$ & \\
\hline CT & $\mathbf{- 0 , 0 0 4}$ & $\mathbf{0 , 7 0 2}$ & $\mathbf{1 , 0 0 0}$ & $\mathbf{0 , 9 8 8}$ & $-\mathbf{0 , 4 5 7}$ & $-\mathbf{0 , 7 4 7}$ & $\mathbf{1}$ \\
\hline
\end{tabular}

Significance level $\boldsymbol{p}<\mathbf{0 , 0 5}$; CW : Carcass weight ; CT : Carcass temperature ; FT : Fasting time ; LFM : Livestock farming mode.

Carcass weight is correlated with most parameters, mainly the age $(r=0.989 ; p>0.0001)$, and the carcass temperature $(r=$ $0.988 ; p>0.0002)$. On the other hand, an inverse relationship between the weight and the fasting time $(r=-0.798 ; p>$ $0.0009)$, While the fasting time and the farming method, their correlation is positive $(r=0.589 ; \mathrm{p}>0.006)$ (Table I).

\section{DISCUSSION}

The results of this study show a variation in post-mortem $\mathrm{pH}$ depending on the muscle type. According to ASHMORE and DOESE (1971) this acidification is related to the type of skeletal fibers constituting each muscle, because several characteristics like morphological, physiological and biochemical differentiate these fibers. JOO in 2017 reports that for cattles the percentage of fibers and their diameters differs depending on the muscle type. The muscle type derives from the relative proportions in composition of different fiber types, this influences muscle metabolism. Knowing that all the muscles studied presented a post-mortem $\mathrm{pH}$ near to neutral.

Analysis of the race effect on $\mathrm{pH}$ p. $\mathrm{m}$ indicates that there is no significant effect $(r=-0.006, p<0.982)$. Our results coincide with those obtained by several authors, who confirm that there are few comparisons between races concerning the $\mathrm{pH}$ post mortem evolution. A lot of experiments involving many races led to the conclusion that racial differences in this field is weak (Menissier et $a l$, 1982). Regarding the effect of sex on this parameter, the variance analysis shows a significant difference in $\mathrm{pH}$ according to sex $(\alpha=0.05 ; \mathrm{p}>0.001)$. Our results are consistent with those of Martin and Freeden (1974) on cattles carcasses. They report that after slaughter, the rate of $\mathrm{pH}$ drop in muscles is slower for males than females of cattles. Similar results were previously announced by Benaissa et $a l$, (2014) and BENAISSA in 2016 on dromedary muscles of the Sahrawi population of 1 hour after slaughter at the Ouargla slaughterhouse and by Bendall in 1973, on cattles muscles. According to Seideman and Crouse (1986), the male animal's muscles have a higher percentage of slow oxidative fibers and less rapid glycolytic fibers. Also Didier Micol et al, (1993) report that generally, for the same muscles type, fibers diameters for males are greater than those for females. Regarding to the age, according to Pearson's correlation, there is a negative relationship between $\mathrm{pH}$ and age with a very strong significant effect $(r=-0.998 ; p>0.0001)$. KADIM et $a l$, (2006) point that the pH vary depending on the animal's age where generally young tend to produce meat with a higher $\mathrm{pH}$ more than older ones due to the lower glycogen level. For carcass weight, our results consist with those obtained by Hopkins et al, (2007), on beef and Kadim et al, (2008), on dromedary. They report that a faster drop in $\mathrm{pH}$ is noted with carcass weight increase. Unlike the study of Przybylski et al, (2015), on pork muscles, shows that an increase in carcass weight does not influence the meat's $\mathrm{pH}$. In addition, about the temperature influence on post-mortem $\mathrm{pH}$, Molette et al, (2003) note on turkey meat (at 40, 20 and $4{ }^{\circ} \mathrm{C}$ after 6 hours) that the rate of $\mathrm{pH}$ drop is higher in the pectoral muscle subjected to the highest temperature $\left(40{ }^{\circ} \mathrm{C}\right)$. Our results also show a negative relationship between these two parameters, according to Pearson's correlation $r=-$ 0.998 with $\mathrm{p}<0.05$. There is also a relationship between the post-mortem $\mathrm{pH}$ of the 4 muscles studied and the livestock farming method $(\mathrm{r}=0.456$ and $\mathrm{p}<0.05)$. Berri, (2015), Lebret and Faure, (2015) and Lebret and PICARD, (2015) report that animal husbandry condition influence muscle properties, in particular the level of energy reserves (glycogen) and post-mortem metabolism. Also, Priolo et al, (2001), announced this influence in a study carried out on cattles raised on grass and others fed with a ration based on concentrated nutriment. Micol et $a l$, (2010) add to the farming method the physical activity's factors at pasture. For food deprivation before animail's slaughter, Nijdam et $a l$, (2005) and Terlouw et $a l,(2015)$, report that it could decrease the glycogen levels and influence the $\mathrm{pH}$, but the results vary depending of the muscles. Therefore, in order to preserve muscles reserves which are metabolized into lactic acid during the post-mortem transformation of muscle into meat; time and conditions of fasting must be optimized for each species. A positive relation ship between the fasting time and the post mortem $\mathrm{pH}(\mathrm{r} 0.745$ with $\mathrm{p}<0.05)$ is noted in our study as well. 


\section{CONCLUSION}

At one hour and a half after slaughter, all post mortem $\mathrm{pH}$ averages measured on four muscles : Cleido-mastoidien, Semi membranosus, Triceps Brachii and Psoas major, located in different parts of the carcass: neck, thigh, shoulder and back respectively, are close to neutrality $(7.14 \geq \mathrm{pH} \geq 6.62)$. For a temperature varying from $35.5^{\circ} \mathrm{C}$ to $24{ }^{\circ} \mathrm{C}$. The post-mortem $\mathrm{pH}$ of first hours (initial $\mathrm{pH}$ ) was influenced by :

The muscle type (the Triceps Brachii $\mathrm{pH}$ is the highest, followed by the Cleido-mastoid's one, for the Semi membranosus and the Psoas major have close values).

Second, the age that has a negative correlation which is highly significant $(r=-0.99 ; \mathrm{p}>0.0001)$.

The carcass weight having a negative relationship ( $\mathrm{r}=$ $0.98 ; \mathrm{p}>0.0003$ ).

The sex, $\mathrm{pH}$ values are higher for males than females. The race, the highest $\mathrm{pH}$ values have been recorded for animals from the Sahrawi population than the Targui one. For parameters controlled by humans;

The fasting time, the extension of its duration is at the origin of an increase in the $\mathrm{pH}$ value $\mathrm{p} . \mathrm{m}$, corresponding to a positive correlation $(r=0.74 ; p>0.0007)$.

The livestock farming method, low $\mathrm{pH}$ values for intensive breeding and higher values for semi-intensive and extensive breeding. post mortem $\mathrm{pH}$ is an important parameter for the analysis of a number of meat quality characteristics. Therefore, it is necessary to generate the best $\mathrm{pH}$ decline estimation for each animal and choose the initial $\mathrm{pH}$ to obtain its ultimate optimum.

\section{REFERENCES}

[1] Ashmore, C. R., et Doese, L. (1971). Comparative Aspects of Muscle Fibre Types in Different Species. Exp. Neurol. 31: 408-418.

[2] Benaissa A., Ould El Hadj-Khelil A., Adamou A., Babelhadj B., Mehirig M., Boufaghes B., Attoussi M., Samili H., Becila S. (2014). Qualité de la viande de dromadaire dans les abattoirs d'Ouargla en Algérie. I. Quelques caractéristiques physico-chimiques de la viande au cours de la maturation, Revue d'élevage et de médecine vétérinaire des pays tropicaux, 67 (4): 223-228.

[3] Benaissa A. (2016). Evolution des qualités physicochimique, biochimique et microbiologique de la viande cameline au cours de son attendrissage et sa conservation selon différents modes. Thèse en vue de l'obtention du diplôme de Doctorat en sciences biologiques spécialité Microbiologie Appliquée. Université Kasdi Merbah Ouargla. Algérie. 105 p.

[4] Bendall J. R. (1973). post mortem changes in muscles. Dans: G.H. Bourne (Ed), The Structure and Function of Muscle, 2nd Ed. Academic Press, New York. p 243- 309.

[5] Berri C. (2015). La viande de volaille : des attentes pour la qualité qui se diversifient et des défauts spécifiques à corriger. In : Numéro spécial, Le muscle et la viande. Picard B., Lebret B. (Eds). INRA Prod. Anim., 28, pages.

[6] Boudjellal A., Becila S., Coulis G., Herrera-Mendez C., Aubry L., Lepetit J., Harhoura K., Sentandreu M.A., Ait Amar H. \& Ouali A. (2008). Is the $\mathrm{pH}$ drop profile curvilinear and either monophasic or polyphasic consequences on the ultimate bovine meat texture, African Journal of Agricultural Research vol. 3 (3), 195-200.

[7] Charnot, Y. (1959). A propos de l'écologie des camélidés. Bull. Soc. Sci. Nat. Phys. Maroc 39 (1) 29 à 39.

[8] Didier Micol, J. Robelin, Y. Geay, (1993). Composition corporelle et caractéristiques biologiques des muscles chez les bovins en croissance et à l'engrais. INRA Productions animales, 1993, 6 (1).61-69.

[9] Faye B. (2013). Classification, history and distribution of the camel dans: Camel meat and meat products (eds: KADIM I.T., MAHGOUB O., FAYE B., FAROUK M.), CABI, U.K.,.1-7, 258 p.

[10] Hocquette J.F., Botreau R., Picard B., Jacquet A., Pethick D.W. and Scollan N.D. (2012) . Opportunities for predicting and manipulating beef quality. Meat Science, 92 (3). 197-209.

[11] Hopkins D., Cassar J., Toohey E. \& Wynn P. (2007). Examination of $\mathrm{pH}$ in lot fed beef for Japan, Proceedings of the New Zealand society of animal production, 67, 436440.

[12] Joo Sung-Hyun, Lee Kyu-Won, Hwa and Joo SeonTea.(2017). Histochemical Charactéristics in Relation to Meat Quality Traits of Eight Major Muscles from Hanwoo Steers, $718-719$

[13] Kadim I.T., Al-Hosni Y., Mahgoub O., Al-Marzooqi W., Khalaf S.K., Al- Maqbaly R.S., Al-Sinawi S.S.H., Al-Amri I.S. (2009). Effect of low voltage electrical stimulation on biochemical and quality characteristics of Longissimus thoracis muscle from one humped camel (Camelus dromedaries), Meat Science 82 77-85.

[14] Kadim IT, Mahgoub O, Al-MarzoogiW, Al-Zadjali S, Annamalai K, Mansour MH. (2006). Effects of age on composition and quality of muscle longissimus thoracis of the Omani Arabian camel (Camelus dromedaries). Meat Sci. 73 619- 625.eat Science 80, 555-569.

[15] Kamoun M. (1995). La viande de dromadaire: production, aspects qualitatifs et aptitude à la transformation, dans: Elevage et alimentation du dromadaire, (éd : TISSERAND J.L.), CIHEAM, options méditerranéennes - série séminaires $\mathrm{n}^{\circ} 13,105-130$.

[16] Klont R.E., Brochs L. \& Eikelenboom G. (1998). Muscle fiber type and meat quality, Meat Science, 49, 219-229.

[17] Lebret B., Faure J. (2015). La viande et les pro- duits du porc : comment satisfaire des attentes qualitatives variées ? In : Numéro spécial, Le muscle et la viande. Picard B., Lebret B. (Eds). INRA Prod. Anim., 28, 111-114.

[18] Lebret B., Picard B. (2015). Les principales composantes de qualité des carcasses et des viandes dans les différentes espèces animales. In : Numéro spécial, Le muscle et la viande. Picard B., Lebret B. (Eds). INRA Prod. Anim., 28, 93-98. 
[19] M.A.D.R., Ministère de l'Agriculture et du Développement Rural. (2013)- Rapport des statistiques agricoles, Alger, $128 \mathrm{p}$.

[20] Martin A.H., Freeden H.T. (1974), post mortem pH changes as related to tenderness and water-holding capacity of muscles from steer, bull and heifer carcasses. Can. J. Anim. Sci., 54, 127-135.

[21] Menissier F., Sapa J., Foulley J.L., Frebling J., Bonaiti B. (1982). Comparison of different sire breeds crossed with Friesan cows/preliminary results. Curr. Top. Vet. Med. Anim. Sci., 21, 94-136

[22] Micol D., Jurie C., Hocquette J.F. (2010). Qualités sensorielles de la viande bovine. Impacts des facteurs d'élevage ? In : Muscle et viande de ruminants. Editions Quae, Versailles, France. 163-172

[23] Molette C., Remignon H., \& Babile R. (2003). Effect of rate of $\mathrm{pH}$ fall on turkey breast meat quality. Br Poult Sci. 44: 787-788.

[24] Nijdam E., Arens P., Lambooij E., Decuypere E., Stegeman J. (2004). Factors influencing bruises and mortality of broilers during catching, transport, and lairage. Poult. Sci., 83, 1610-1615.

[25] Picard B., Jurie C., Cassar M., Hocquette J.F. (2002). Typologie et myogenèse des fibres musculaires chez le bovin. Prod. Anim., 16: 125-131.

[26] Priolo A., Micol D., Agabriel J. (2001). Effects of grass feeding systems on ruminant meat colour and flavor. Anim. Res., 50, 185-200.

[27] Seideman S.C., Crouse J.D. (1986). The effects of sex condition, genotype and diet on bovine muscle fiber characteristics. Meat Sci., 17 : 55-72.

[28] Siboukeur O. (2007). Etude du lait camelin collecté localement : caractéristiques physico-chimiques et microbiologiques ; aptitudes à la coagulation. Thèse de Doctorat à l'institut national agronomique El-HarrachAlger. Algérie p.135.

[29] Terlouw E.M.C. (2015). Cassar-Malek I., Picard B., Bourgouet C. Deiss V., Arnould C., Berri C., Duval E., Lefévre F., Lebret B., Stress en élevage et à l'abattage : impacts sur les qualités des viandes. In : Numéro spécial, Le muscle et la viande. Picard B., Lebret B. (Eds). INRA Prod. Anim., 28 .169-182.

[30] Vergara H., Molina A. \& Gallego L. (1999). Influence of sex and slaughter weight on carcass and meat quality in light and medium weight lambs produced in intensive systems, Meat Science, 52, 221-226.

[31] Wiesław Przybylski1 , Katarzyna Kajak-Siemaszko1 , Danuta Jaworska1, Stanisław Niemyjski, (2015). Qualité de la viande porcine selon le poids de carcasse. La revue scientifique Viandes \& Produits Carnés. janvier 1-6 www.viandesetproduitscarnes.com 